\title{
ARTI PENTING NILAI-NILAI DAN NORMA HUKUM DALAM BERPOLITIK PRAKTIS
}

\author{
Ronny Winarno \\ Fakultas Hukum Universitas Merdeka Pasuruan \\ e-mail:winarno89@yahoo.co.id
}

\begin{abstract}
ABSTRAK
Dalam penyelenggaraan sistem pemerintahan terdapat proses perolehan kekuasaan legislatif dan yudikatif yang dilakukan melalui mekanisme pemilu yang di dalamnya terdapat prinsip berpolitik praktis. Prinsip-prinsip berpolitik sangat diperlukan oleh partai politik dalam melaksanakan proses berpolitik praktis. Berpolitik praktis harus memahami nilai-nilai dan norma hukum sesuai peraturan perundang-undangan yang berlaku guna mewadahi kepentingan rakyat agar tercipta berpolitik praktis yang baik dan tidak bertentangan dengan norma hukum. Kata Kunci: nilai-nilai dan norma hukum, berpolitik praktis, kekuasaan.

\section{ABSTRACT}

Govermental appliance include a process of acquiring legislative and judicial power that is done through the mechanism of elections in which there is a principle in politics. The principles of politics is needed by the political parties in carrying out the process of practical politics. Politician must understand the values and legal norms corresponding legislation, in order to accommodate the interests of people, so that may create a good political practice and does not conflict with legal norms.
\end{abstract}

Keywords: value and legal norms, practical politics, powers.

\section{PENDAHULUAN}

Hakikat berpolitik praktis yang berkaitan dengan kekuasaan dalam sistem pemerintahan, maka diasumsikan dan diartikan adanya hubungan yang signifikan dengan cara-cara memperoleh kekuasaan legislatif dan kekuasaan eksekutif. Keterkaitan hubungan ini direfleksikan pada suatu kondisi dan situasi yang saling berhadapan antara kepentingan politik dengan cara-cara yang ditempuh (model berpolitik), yang akan dilakukan dalam rangka mewujudkan apa yang dicita-citakan dalam domain partai politik. Dalam hal ini cara-cara yang ditempuh pada konteks berpolitik didasarkan pada landasan konstitusional Pasal 18 ayat (3) UndangUndang Dasar Negara Republik Indonesia Tahun 1945 (selanjutnya disingkat dengan UUD 1945), akan menghasilkan kekuasaan yang sangat bisa berpengaruh pada pelaksanaan sistem pemerintahan.

Berpolitik praktis tidak bisa dilepaskan dengan nilai-nilai dan norma hukum sebagai pedoman dalam berpolitik dan sebagai bingkai menyelesaikan beragam problematika berpolitik yang akan selalu mengiringi kiprah politik dan perilaku politik. Oleh sebab itu kedudukan nilai-nilai dan norma hukum harus dilengkapi dengan penormaan dan politik hukum yang tegas dan mencakup substansi pembentukan peraturan perundang-undangannya ataulaw making process, penerapannya atau implementation, dan penegakan hukumnya atau law of enforcement.

Pembentukan peraturan perundang-undangan akan mewarnai corak hukum yang dibentuk berikut karakteristiknya. Penerapan hukumnya akan terlihat efektif ataukah tidak efektif. Sedangkan mengenai penegakan hukumnya sangat tergantung pada beberapa komponen penting yang saling terkait.

Penegakan hukum tidak bisa lepas dari 4 (empat) rangkaian komponen penting, yaitu: adanya kaidah hukum atau peraturan; aparat penegak hukum; dan fasilitas yang diperlukan; serta kesadaran hukum masyarakat. ${ }^{1}$ Penegakan hukum pada prinsipnya sebagai upaya melaksanakan atau menerapkan aturan hukum sesuai dengan yang sudah ditetapkan. Dapat pula dikatakan merupakan penerapan yang serasi

\footnotetext{
${ }^{1}$ Soerjono Soekanto dan Mustafa Abdullah, Sosiologi Hukum dalam Masyarakat, Rajawali, Jakarta, 1982, h. 14.
} 
dari nilai-nilai dan kaidah-kaidah yang kemudian terwujud dalam pola perilaku. Dalam berpolitik, jika selama belum ada kesadaran akan adanya pelbagai pengertian hukum dan landasan berpikir berpolitik yang baik yang sesuai dengan norma hukum, agaknya sukar sekali untuk mengalami proses berpolitik dan pelaksanaan penegakan hukum yang baik, yang menurut beberapa kalangan berintikan pada demokrasi dan keadilan yang kemudian bermuara pada kehidupan bermasyarakat, berbangsa dan bernegara berdasarkan Pancasila.

Selanjutnya jika pemahaman nilai-nilai dan norma hukum dalam berpolitik praktis tidak dipahami demi undang undang dan kepentingan masyarakat, bangsa dan negara tentu akan terjadi perilaku berpolitik yang arogan, dan hanya untuk mengejar keuntungan dan kekuasaan semata. Disinilah problematik hukum yang senantiasa akan saling tarik-menarik antara harapan dan kenyataan atau das sollen dan das sein dalam mewujudkan model atau pola berpolitik yang Pancasilais. Sehingga permasalahannya jika dilihat dari perspektif pisau analisis negara kesejahteraan, adalah bagaimana memahami nilai-nilai dan norma hukum dalam berpolitik praktis sebagaimana diuraikan di bawah ini.

\section{PEMBAHASAN}

\section{Prinsip-Prinsip Berpolitik Praktis}

Berkenaan dengan problematik hukum pemahaman tentang nilai-nilai dan norma hukum tidak bisa mengabaikan prinsip dasar filsafati berpolitik praktis yang seiring dengan pola penegakan hukumnya sebagaimana tersurat di dalam UUD 1945 dengan substansi yang berikut:

Pertama, Alinea ke-4 Pembukaan UUD 1945 yang menegaskan bahwa untuk membentuk suatu pemerintahan negara Indonesia yang dapat melindungi segenap bangsa Indonesia dan untuk seluruh tumpah darah Indonesia dan untuk memajukan kesejahteraan umum, mencerdaskan kehidupan bangsa dan ikut melaksanakan ketertiban dunia yang berdasarkan kepada kemerdekaan, perdamaian abadi dan keadilan sosial, maka disusunlah kemerdekaan bangsa Indonesia itu dalam suatu Undang-Undang Dasar Negara Republik Indonesia yang terbentuk dalam suatu susunan Negara Republik Indonesia yang berkedaulatan rakyat dengan berdasarkan kepada Ketuhanan Yang Maha Esa, Kemanusiaan yang adil dan beradab, Persatuan Indonesia dan
Kerakyatan yang dipimpin oleh hikmat kebijaksanaan dalam permusyawaratan/perwakilan, serta dengan mewujudkan suatu keadilan sosial bagi seluruh rakyat Indonesia.

Dari bunyi alinea ke-4 ini tersirat ada nilai -nilai dasar, arah dan tujuan dalam melakukan berpolitik praktis, yang kesemuanya dimaksudkan untuk mewujudkan kehidupan bermasyarakat, berbangsa dan bernegara guna mewujudkan tata tentrem kerta raharja yang sejalan dengan karakteristik negara kesejahteraan. Secara normatif diartikan disini, bahwa kehidupan kebangsaan ini perlu dicapai dengan melakukan dan mempertahankan prinsipprinsip yang terkait dengan: Prinsip tujuan negara; Prinsip demokrasi yang baik; Prinsip ketuhanan dan kemanusiaan; Prinsip persatuan dan kepemimpinan; dan Prinsip pencapaian keadilan sosial.

Kedua, Pasal-pasal dalam UUD 1945 yang berkaitan dengan berpolitik praktis. Pasal 1 UUD 1945 (tentang Bentuk dan Kedaulatan) menegaskan sebagai berikut: Negara Indonesia merupakan negara kesatuan yang berbentuk Republik, yang kedaulatan berada di tangan rakyat dan dilaksanakan menurut Undang-Undang Dasar, serta Negara Indonesia adalah negara hukum.

Berdasarkan pada Pasal 4 UUD 1945 tentang Kekuasaan Pemerintahan Negara menegaskan bahwa Presiden Republik Indonesia memegang kekuasaan pemerintahan menurut Undang-Undang Dasar, serta dalam melaksanakan kewajibannya Presiden dibantu oleh satu orang Wakil Presiden.

Pasal 28 UUD 1945 menegaskan bahwa Kemerdekaan berserikat dan berkumpul, serta mengeluarkan pikiran dengan lisan dan tulisan dan sebagainya ditetapkan dengan undang-undang.

Pasal 33 UUD 1945 tentang Perekonomian Nasional dan Kesejahteraan Sosial menegaskan: Perekonomian disusun sebagai usaha bersama berdasar atas asas kekeluargaan; dan Cabang produksi yang penting bagi negara dan yang menguasai hajat hidup orang banyak dikuasai oleh negara; serta, Bumi dan air dan kekayaan alam yang terkandung di dalamnya dikuasai oleh negara dan dipergunakan untuk sebesarbesar kemakmuran rakyat. Perekonomian nasional diselenggarakan berdasar atas demokrasi ekonomi dengan prinsip kebersamaan, efisiensi berkeadilan, berkelanjutan, berwawasan lingkungan, kemandirian serta dengan menjaga keseimbangan kemajuan dan kesatuan ekonomi nasional. 
Jika mendasarkan pada substansi berpolitik praktis terdapat beberapa prinsip penting yang saling terkait antara satu dengan yang lainnya, yaitu:

Pertama, Prinsip tentang kemerdekaan berserikat, berkumpul dan mengeluarkan pendapat sebagai bagian hak asasi manusia yang diakui dan dijamin dalam UUD 1945.

Kedua, Prinsip tentang memperkokoh kemerdekaan berserikat, berkumpul dan mengeluarkan pendapat yang merupakan bagian dari upaya untuk mewujudkan kehidupan kebangsaan yang kuat dalam negara kesatuan Republik Indonesia yang merdeka, bersatu, berdaulat, demokratis dan berdasarkan hukum serta kemakmuran dan berkeadilan sosial.

Ketiga, Prinsip tentang adanya kaidah-kaidah demokrasi yang menjunjung tinggi kedaulatan rakyat, transparansi, keadilan, aspirasi, tanggung jawab dan perlakuan yang tidak diskriminatif dalam Negara Kesatuan Republik Indonesia yang harus diberi landasan hukum.

Keempat, Prinsip tentang kedudukan partai politik yang merupakan salah satu wujud partisipasi masyarakat yang penting dalam mengembangkan kehidupan demokrasi yang menjunjung tinggi kebebasan, kesetaraan, kebersamaan dan kejujuran. ${ }^{2}$

Beberapa prinsip penting tersebut akan mendasari pembentukan, pemeliharaan dan pengembangan partai politik yang pada hakikatnya adalah merupakan salah satu bentuk pencerminan hak warga negara untuk berserikat, berkumpul dan mengeluarkan pendapat. Melalui partai politik rakyat dapat mewujudkan haknya untuk menyatakan pendapat tentang arah kehidupan dan masa depannya dalam bermasyarakat dan bernegara.

Dengan demikian dalam hal berpolitik praktis, prinsip-prinsip berpolitik sangat diperlukan oleh partai politik dalam membantu terlaksananya proses berpolitik praktis yang memahami nilai-nilai dan norma hukum sesuai dengan peraturan perundangundangan yang berlaku. Oleh sebab itu terdapat beberapa konsep pemahaman bagi partai politik yang akan mewadahi kepentingan rakyat yang melaksanakan berpolitik praktis yang baik, yaitu:

\footnotetext{
${ }^{2}$ Lihat di dalam konsideran menimbang huruf a, b, c, d Undang-Undang Nomor 31 Tahun 2002 tentang Partai Politik, yang kemudian telah diganti dengan Undang-Undang Nomor 2 Tahun 2008 tentang Partai Politik dan terakhir diganti dengan Undang-Undang Nomor 2 Tahun 2011 tentang Partai Politik.
}

Pertama, Diperlukan partai politik yang menjadi komponen penting dalam sistem politik demokrasi;

Kedua, Perlu penataan kepartaian yang bertumpu pada kaidah-kaidah kedaulatan rakyat, yaitu memberikan kebebasan, kesetaraan dan kebersamaan. Melalui kebebasan yang bertanggungjawab, maka segenap warga negara memiliki hak untuk berkumpul dan berserikat untuk mewujudkan cita-cita politiknya secara nyata. Kesetaraan merupakan prinsip yang memungkinkan segenap warga negara berpikir dalam kerangka kederajatan sekalipun kedudukan, fungsi dan peran masing-masing berbeda. Sedangkan kebersamaan merupakan wahana untuk mencapai tujuan berbangsa dan bernegara sehingga segala bentuk tantangan lebih mudah dihadapi.

Ketiga, Di dalam sistem politik demokrasi, kebebasan dan kesetaraan tersebut diimplementasikan agar dapat merefleksikan rasa kebersamaan yang menjamin terwujudnya cita-cita kemasyarakatan secara utuh.

Keempat, Partai politik sebagai aset nasional berlangsung berdasarkan prinsip perubahan dan kesinambungan yang makin lama makin menumbuhkan kedewasaan dan tanggung jawab berdemokrasi.

Berdasarkan konsep pemahaman bagi partai politik yang akan mewadahi kepentingan rakyat yang melaksanakan berpolitik praktis diharapkan dapat melakukan proses pembelajaran berpolitik yang diperlukan oleh masyarakat. Adapun pemerintah sebagai penyelenggara dan pembina di dalam melakukan proses kehidupan bermasyarakat, berbangsa dan bernegara dapat melakukan penataan dan pengaturan sesuai dengan lingkup dan sasaran pembinaan berpolitik praktis yang dijiwai dan disemangati oleh Pancasila.

Titik tolak terselenggaranya prinsip-prinsip berpolitik praktis yanag baik sangat tergantung pada kedewasaan dan kematangan membentuk pola pikir, mengatur dan menentukan cara-cara mencapai tujuan berpolitik untuk mewujudkan kehidupan bermasyarakat, berbangsa dan bernegara sesuai dengan karakteristik bangsa Indonesia. Disinilah makin dirasakan pentingnya untuk mempertahankan dan melaksanakan prinsip-prinsip berpolitik praktis yang baik agar dapat menghindari perpecahan bangsa dan konflik sebagai bias kepentingan dalam berpolitik. 
Pemahaman Nilai-Nilai dan Norma Hukum dalam Berpolitik Praktis

Berpolitik praktis yang baik di Indonesia seolah hanya menjadi slogan yang terjadi sejak era Orde Lama sampai dengan era reformasi. Perguliran perkembangan politik demikian kental dengan nilainilai kepentingan memperoleh kekuasaan. Siapa pun yang kuat seolah yang mampu mengendalikan kekuasaan. Dalam prakteknya tidak jarang akan terjadi benturan kepentingan dan benturan fisik saling melempar statement politik dan berprinsip menjatuhkan rival politik.

Bahkan tidak jarang pula sebagai akibat adanya konfrontasi kepentingan politik akan berimbas kepada kebijakan pemerintahan baik di pusat maupun di daerah. Pada akhirnya rakyatlah yang akan menderita dan mengalami berbagai kesulitan dalam memperoleh layanan yang sesuai dengan peraturan yang berlaku. Hal ini sebagai bentuk ketimpangan kurangnya pemahaman nilai-nilai dan norma hukum, sehingga para pemangku pemerintahan akan terpengaruh dengan situasi politik yang tidak sejalan dengan tujuan berpolitik untuk kepentingan bangsa dan mengedepankan kepentingan rakyat.

Terdapat hubungan penting antara nilai-nilai dan norma hukum dengan berpolitik praktis yang terlihat dalam Skema 1.

Berdasarkan skema tersebut, berangkat dari nilainilai keadilan, kemanfaatan dan kepastian hukum yang direfleksikan dalam norma hukum harus dijadikan pedoman melaksanakan berpolitik praktis. Dengan demikian jika nilai-nilai dan norma hukum sebagai hukum positif dalam bidang politik tidak dipahami dan dilaksanakan sesuai dengan ketentuan yang berlaku akan terjadi beberapa permasalahan sebagai berikut: Adanya disharmonisasi di bidang politik; Terbentuknya kelompok-kelompok tertentu yang berorientasi sikap dukung mendukung dalam berpolitik praktis; Terjadi pengingkaran nilai-nilai dan norma hukum yang dituangkan dalam hukum positif dalam rangka berpolitik praktis; Terjadi konflik kepentingan yang dapat berimbas dan berpengaruh pada keputusan guna kepentingan publik yang cenderung tidak partisiparis; dan Sikap inkonsisten pada tujuan berpolitik praktis.

Dari beberapa problematika dimaksud menunjukkan adanya kelemahan-kelemahan berpolitik yang akan muncul setiap saat dan bisa menjadi penyebab lemahnya pemahaman berpolitik di dalam masyarakat. Akibatnya masyarakat akan bersikap apatis, masa bodoh, bahkan tidak mempedulikan bagaimana sebaiknya memberikan solusi sebagai salah satu bentuk penyelesaian manakala terjadi konflik berpolitik. Pentingnya pemahaman nilainilai dan norma hukum dalam berpolitik praktis sangat diperlukan guna mewujudkan kondisi sistem berpolitik yang sesuai dengan nilai-nilai Pancasila serta bersesuaian dengan tujuan negara mewujudkan kemakmuran.

Pemahaman nilai-nilai dan norma hukum dalam berpolitik praktis pada prinsipnya juga dapat dikatakan sebagai salah satu konkritisasi sistem demokrasi yang diharapkan dapat merubah paradigma masyarakat untuk lebih memperhatikan perkembangan sistem berpolitik serta akibat pengaruh globalisasi dalam berbagai fenomena ketatanegaraan,

Skema 1.

Hubungan Nilai-Nilai dan Norma Hukum dengan Berpolitik Praktis

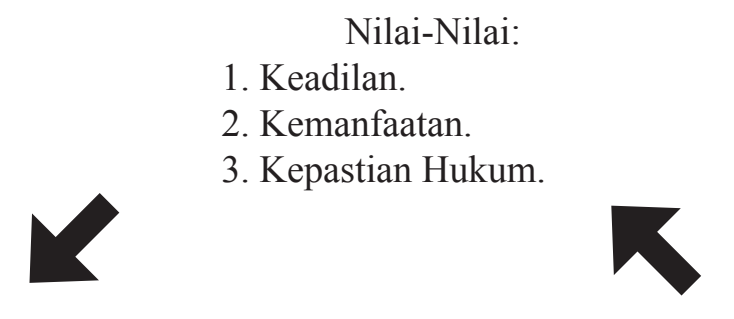

Norma Hukum:

1. UUD 1945.

2. UU tentang Partai Politik.

3. UU tentang Pemerintahan Daerah.

4. UU tentang Mahkamah Konstitusi.

5. UU tentang Penyelenggara Pemilu.
Berpolitik Praktis:

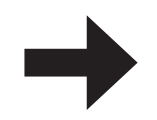

1. Berpolitik sesuai aturan.

2. Pelaku politik yang taat hukum.

3. Adanya peraturan berpolitik. 
politik, hukum, budaya, sosial bahkan pertahanan dan keamanan negara yang kesemuanya itu memerlukan bingkai demokrasi yang dapat diterima oleh seluruh masyarakat.

Meskipun sistem demokrasi di Indonesia telah menyatu dengan kehidupan masyarakat, akan tetapi pernik-pernik implementasi sistem demokrasi dalam rangka berpolitik praktis masih menyisakan berbagai kendala, perbedaan interpretasi atas peraturan perundang-undangan, bahkan bila samasama mempertahankan kepentingan, tidak jarang antara kelompok kepentingan bahkan golongan dan wadah sosial tertentu akan saling konfrontatif mempertahankan, memperebutkan dan berusaha menguasai kekuasaan tertentu dengan cara berdalih atas nama demokrasi yang kemudian tidak segansegan menggunakan topeng hukum sebagai opsi terakhir untuk menindak terhadap konkurensinya agar sadar atas betapa besarnya kekuasaan yang dipegangnya dengan segala atribut atas nama sistem demokrasi yang serta merta akan berdampak tiadanya keadilan dan kepastian hukum.

Secara normatif sistem demokrasi tersuratkan dalam konstitusi, yaitu UUD 1945 dan menjadi barometer kehidupan bermasyarakat, berbangsa dan bernegara diantaranya dalam Pasal 1 UUD 1945 dimana mencakup adanya kedaulatan rakyat dan Indonesia sebagai negara hukum. Sehingga dalam ketentuan ini dapat digunakan sebagai payung hukum dan alur pemahaman nilai-nilai dan norma hukum dalam berpolitik praktis dengan segala konsekuensinya yang dituangkan dalam Skema 2.

Berbagai hambatan akan terjadi jika nilai-nilai dan norma hukum tidak dipahami secara proporsional berdasarkan pearturan perundang-undangan yang berlaku diantaranya dalam suatu kepentingan tertentu akan menyebabkan terjadinya amuk massa dan tindakan destruktif yang tidak terkendalikan sebagai akibat adanya pemahaman yang tidak sejalan dalam proses berpolitik dan tidak seimbangnya antara kepentingan politik dengan pemahaman pengaturan yang berlaku. Tidak sesuainya antara nilai-nilai dan norma hukum dengan fakta hukum dalam berpolitik praktis, pada akhirnya hanya akan menciptakan sikap apatis atas hukum dan tidak memperhatikan nilai-nilai keadilan, kemanfaatan dan kepastian hukum.

Ketimpangan berpolitik menjadi tanggung jawab pemerintah dan partai politik yang sama-sama memiliki kewajiban mengembang demokrasi dan melaksanakan proses berpolitik praktis yang tidak destruktif. Pemahaman nilai-nilai dan norma hukum sebagai refleksi atas berbagai peraturan hukum di bidang politik yang harus dipatuhi oleh masyarakat dan seluruh komponen pelaku proses berpolitik termasuk penegak hukumnya merupakan salah satu pedoman dan standar berpolitik agar aturan yang

Skema 2.

Alur Pemahaman Nilai-Nilai dan Norma Hukum dalam Berpolitik Praktis

Cita Bangsa/Tujuan Negara

(Kesejahteraan Rakyat)
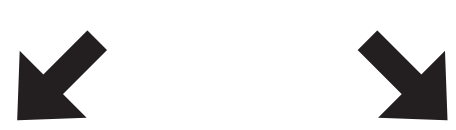
Nilai-Nilai:
1. Keadilan
2. Kemanfaatan
3. Kepastian Hukum
Norma Hukum:
1. Hak dan Kewajiban
2. Tanggung jawab Hukum
3. Akibat Hukum
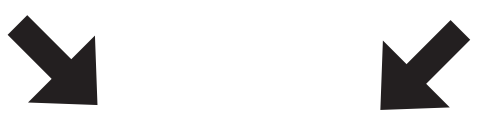

Penting dan perlu dalam berpolitik:

1. Tetap berpedoman pada hukum.

2. Hindari konflik kepentingan.

3. Ciptakan harmonisasi, sinkronisasi, keselarasan, keserasian dan keseimbangan dalam berpolitik. 
sudah ditetapkan dimaksud bisa ditegakkan sesuai dengan tingkat penegakannya. Semua pihak harus menerima, memahami dan melaksanakan secara konsekuen atas proses berpolitik yang seiring dengan penegakan hukumnya, yang dalam kondisi tertentu akan terjadi perubahan-perubahan sesuai dengan perjalanan sistem pemerintahah yang berlangsung serta politik hukum ketentuan perundangan yang berlaku.

\section{Penjabaran Pemahaman Nilai-Nilai dan Norma Hukum dalam Berpolitik Praktis (Prioritas Penegakan Hukum) dalam Perspektif Negara Kesejahteraan}

Hakikat pemahaman nilai-nilai dan norma hukum dalam berpolitik praktis tidak hanya dimaksudkan hanya untuk dijadikan pedoman dalam berpolitik, akan tetapi harus dapat dilaksanakan sesuai dengan proses berlangsungnya berpolitik praktis dalam mencapai tujuan, yaitu:

Pertama, Nilai-nilai dan norma hukum harus mampu mengakomodir dan menyelesaikan berbagai persoalan yang terjadi dalam proses berpolitik.

Kedua, Nilai-nilai dan norma hukum harus senantiasa digunakan sebagai alat dalam menentukan pilihan kepentingan dalam berpolitik dengan memprioritaskan kepentingan rakyat, bangsa dan negara.
Ketiga, Nilai-nilai dan norma hukum harus digunakan secara konsisten dan tidak dilakukan intepretasi yang bertentangan dengan konstitusi dan tujuan negara dalam mewujudkan kemakmuran sebagai bagian kehidupan bermasyarakat, berbangsa dan bernegara.

Keempat, Nilai-nilai dan norma hukum harus digunakan sebagai roh berpolitik sebagaimana substansinya yang mencakup adanya keadilan, kemanfaatan dan kepastian hukum yang akan memberikan jaminan dan perlindungan dalam proses berpolitik praktis.

Berdasarkan konsekuensi harus dilaksanakannya nilai-nilai dan norma hukum dalam berpolitik praktis menunjukkan adanya sifat imperatif sebagai hukum positif. Antara nilai-nilai dan norma hukum dengan perilaku berpolitik harus sinergi yang didasarkan pada peraturan perundang-undangan, sehingga menciptakan pemahaman bagi masyarakat taat hukum, taat asas dan mendukung terlaksananya sistem berpolitik sesuai dengan kepribadian bangsa Indonesia. Berikut keterkaitan nilai-nilai dan norma hukum dalam berpolitik praktis dalam Tabel 1 .

Meskipun nilai-nilai dan norma hukum sudah diterapkan, namun tidak jarang masih terjadi kendala dalam berpolitik praktis, antara lain bisa terjadi detournement de pouvoir sehingga atau pun karena pemanfaatan politik yang kemudian mengabaikan

Tabel 1.

Keterkaitan Nilai-Nilai dan Norma Hukum yang Cenderung Diabaikan dalam Berpolitik Praktis

\begin{tabular}{clll}
\hline No & Nilai-Nilai Dasar & \multicolumn{1}{c}{ Norma Hukum } & \multicolumn{1}{c}{ Pemahamannya } \\
\hline 1. & Keadilan & $\begin{array}{l}\text { Hak dan kewajiban yang } \\
\text { terkait Pasal 28 UUD 1945 }\end{array}$ & $\begin{array}{l}\text { Dalam menggunakan kemerdekaan berserikat dan } \\
\text { berkumpul, mengeluarkan pikiran dengan lisan dan } \\
\text { tulisan dan sebagainya ditetapkan dengan undang-undang } \\
\text { dan mencerminkan keadilan. }\end{array}$ \\
& & $\begin{array}{l}\text { Parpol dalam menggunakan hak dan kewajibannya harus } \\
\text { Hak dan kewajiban } \\
\text { berkenaan dengan UU No. 2 } \\
\text { Tahun 2011 tentang Parpol. }\end{array}$ &
\end{tabular}

2. Kepastian hukum Penyelenggaraan pemerintahan berdasar UU No. 23 Tahun 2014 tentang Pemerintahan Daerah Penyelenggaraan pemilu berdasar UU No. 15 Tahun 2011 tentang Penyelenggaraan Pemilu

3. Kemanfaatan Kewenangan pusat dan hukum daerah diklasifikasikan sebagaimana Pasal 9 ayat (1) Penyelenggaraan pemerintahan berpedoman pada asas umum penyelenggaraan negara yang baik.

Pelaksanaannya didasarkan pada asas-asas penyelenggaraan pemilu yang luber dan jurdil.

Pelaksanaannya diiringi dengan dengan tugas dan tanggung jawab yang harus memberikan manfaat bagi UU No. 23 Tahun 2014 
nilai-nilai dan norma hukum yang berlaku. Disinilah kemudian jika sangat merugikan negara diperlukan konsistensi pola penegakan hukum yang sesuai dengan tipikal negara Indonesia sebagai negara hukum yang dengan tegas diatur dalam Pasal 1 ayat (3) UUD 1945.

Dengan demikian pemahaman nilai-nilai dan norma hukum dalam berpolitik praktis adalah sejalan dengan karakteristik Indonesia sebagai negara hukum. Nilai dan norma hukum jika dikaitkan dengan berpolitik praktis bisa digunakan sebagai pengendali, mencegah dan menindak perilaku berpolitik praktis yang bertentangan dengan hukum. Berarti nilainilai dan norma hukum lebih mengarah pada proses penegakan hukum yang harus diterapkan sesuai dengan dampak berpolitik praktis tersebut.

Semua tindakan yang dilakukan dalam berpolitik praktis harus berdasarkan hukum sesuai dengan konteks negara hukum. Menurut Bagir Manan dan Kuntana Magnar, dalam arti umum negara berdasarkan hukum adalah negara dimana ada saling percaya antara rakyat dan pemerintah. Rakyat percaya pemerintah tidak akan menyalahgunakan kekuasaannya, dan sebaliknya pemerintah percaya, bahwa dalam menjalankan wewenangnya, pemerintah akan dipatuhi dan diakui oleh rakyat. Sedangkan dalam arti khusus, negara berdasarkan hukum diartikan semua tindakan negara atau pemerintah harus didasarkan pada ketentuan hukum atau dapat dipertanggungjawabkan secara hukum. ${ }^{3}$

Negara hukum adalah negara yang pemerintah dan pemerintahannya serta masyarakat dalam bertindak selalu mengutamakan dan menegakkan hukum. Tentunya hal ini menjadi idealisme hukum dalam berpolitik. Tanpa adanya dukungan penegakan hukum dalam berpolitik, yang merupakan bagian integral dalam proses mewujudkan negara hukum, maka akan terjadi kesenjangan dan ketidakseimbangan hak dan kewajiban berpolitik. Sebab justru dengan penegakan hukum tersebut akan mengeleminir tindakan arogansi dan sifat melanggar hukum. Adapun dalam proses penegakan hukum itu sendiri tidak boleh ada diskriminasi atau perlakuan yang berbeda-beda. Oleh karena itu prinsip equality before the law atau perlakuan yang sama di depan hukum harus senantiasa ditegakkan mengingat dalam

\footnotetext{
3 Bagir Manan dan Kuntana magnar, "Mewujudkan Kedaulatan Rakyat Melalui Pemilihan Umum" dalam Bagir Manan (editor) Kedaulatan Rakyat.
}

proses berpolitik akan menjadi ajang pertarungan kepentingan dan perpolitikan guna memperoleh kekuasaan.

Penegakan hukum menurut Purnadi Purbacaraka pada prinsipnya merupakan kegiatan menyerasikan hubungan nilai-nilai yang terjabarkan dalam kaidahkaidah atau pandangan-pandangan menilai yang mantap dan mengejewantah serta sikap tindak sebagai rangkaian penjabaran nilai tahap akhir untuk menciptakan, memelihara dan mempertahankan kedamaian pergaulan hidup. Makna menciptakan pergaulan hidup berarti sebagai social engineering sedangkan memelihara dan mempertahankan perdamaian hidup berarti sebagai social control.

Penerapan penegakan hukum tidak dapat dipisahkan dengan keberadaan sistem hukum dimana menurut Lawrence Friedman terdapat tiga unsur penting dalam sistem hukum yang meliputi struktur, substansi, dan kultur hukum.

Struktur hukum adalah pola yang memperlihatkan tentang bagaimana hukum itu dijalankan menurut ketentuan-ketentuan formalnya. Dalam struktur ini memperlihatkan tentang bagaimana pengadilan, pembuatan undang-undang dan badan-badan serta bagaimanakah proses hukum itu berjalan dan dijalankan. Berarti disini sebagai proses berlangsungnya sistem tersebut sesuai dengan tatanan yang sudah ditetapkan. Sedangkan mengenai substansi hukum adalah peraturan-peraturan yang digunakan oleh para pelaku hukum pada waktu melakukan perbuatan-perbuatan serta hubungan-hubungan hukum. Peraturan-peraturan dimaksud sebagai legalitas dan dasar hukum pelaksanaan perbuatan yang dilakukan masyarakat diantaranya dalam berpolitik. Selanjutnya tentang kultur hukum pada prinsipnya menyangkut tentang sikap-sikap, perilaku dan harapan serta nilai-nilai yang mempengaruhi bekerjanya hukum. ${ }^{4}$

Bilamana terjadi kepincangan pada salah satu faktor tersebut tentunya akan mengakibatkan seluruh sistem terkena pengaruh. Oleh karena itu agar dalam penegakan hukum itu dapat berjalan efektif sesuai dengan tujuannya, maka keempat faktor tersebut harus saling mendukung. Dalam implementasi penegakan hukum juga akan mengalami adanya pengaruh-pengaruh dari faktor-faktor non yuridis,

\footnotetext{
${ }^{4}$ Satjipto Rahardjo, Ilmu Hukum, Alumni, Bandung, 1986, h. 167.
} 
sehingga untuk itulah faktor-faktor tersebut juga perlu dipertimbangkan.

Dengan demikian hakikat penegakan hukum jika dikaitkan dengan pemahaman nilai-nilai dan norma hukum dalam berpolitik adalah sebagai dasar konsep penyelesaian persoalan hukum yang akan terjadi dalam proses politik. Justru secara normatif penegakan hukum akan mengiringi proses berlangsungnya politik dimana konkritisasi penegakan hukum sebagai salah satu bentuk penerapan hukum dan konsekuensi Indonesia sebagai negara hukum yang harus menjamin dan melindungi rakyatnya.

Mendasarkan pendapat Made Arya Utama, negara hukum disebut pula sebagai negara kesejahteraaan. Jadi negara negara kesejahteraan adalah negara hukum yang memperhatikan pada upaya mewujudkan kesejahteraan orang banyak. ${ }^{5}$ Negara kesejahteraan merupakan suatu bentuk pemerintahan demokratis, yang menegaskan, bahwa negara bertanggungjawab terhadap kesejahteraan rakyat yang minimal. Disinilah terdapat keterkaitan fungsi pemahaman nilai-nilai dan norma hukum dalam berpolitik adalah untuk mendukung terwujudnya tujuan negara.

Menurut RMAB Kusuma, negara kesejahteraan mengandung asas kebebasan atau liberty, asas kesetaraan hak atau equality maupun asas persahabatan atau fraternity, serta kebersamaan atau mutuality, yang dapat disamakan dengan asas kekeluargaan atau gotong-royong. ${ }^{6}$ Oleh karena itu menurut Lemaire, negara kesejahteraan disebut pula sebagai negara hukum modern yang memiliki tujuan tidak hanya menjaga keamanan, tetapi juga menyelenggarakan kesejahteraan umum yang dilakukan oleh pemerintah. ${ }^{7}$

Ciri-ciri negara hukum modern menurut Bachsan Mustafa, meliputi: Corak negara merupakan welfare state, suatu negara yang mengutamakan kepentingan seluruh rakyat; dan Staatsonhouding telah diganti dengan staatsbemoeienis, yang artinya negara dapat ikut campur dalam semua lapangan kehidupan masyarakat; dan Ekonomi liberal telah diganti dengan sistem ekonomi yang lebih dipimpin oleh pemerintah

\footnotetext{
${ }^{5}$ I Made Arya Utama, Hukum Lingkungan, Sistem Hukum Perizinan, Berwawasan Lingkungan untuk Pembangunan Berkelanjutan, Pustaka Sutra, Bandung, 2007, h. 47.

${ }^{6}$ RMAB Kusuma, Negara Kesejahteraan dan Jaminan Sosial, Jurnal Konstitusi Vol. 3. Pebruari 2006, Mahkamah Konstitusi RI, Jakarta, 2006, h. 160.

${ }^{7}$ Diana Halim Koentjoro, Hukum Administrasi Negara, Ghalia Indonesia, Bogor, 2004, h. 37.
}

pusat atau centraal geleide ekonomie; serta, Tugas dari suatu welfare state merupakan bestuurszorg, yaitu menyelenggarakan kesejahteraan umum; dan Tugas negara menjaga keamanan dalam arti luas, yaitu keamanan sosial di segala lapangan kehidupan masyarakat. ${ }^{8}$

Sedangkan tujuan pokok negara kesejahteraan adalah mengontrol dan mendayagunakan sumber daya sosial ekonomi untuk kepentingan publik, menjamin distribusi kekayaan secara adil dan merata, mengurangi kemiskinan, dan menyediakan asuransi sosial (pendidikan dan kesehatan) bagi masyarakat miskin serta menyediakan subsidi untuk layanan sosial dasar bagi disadvantage people, serta memberi proteksi sosial bagi setiap warga negara. ${ }^{9}$

Menciptakan kesejahtaraan masyarakat tidak bisa lepas dari tugas negara dalam melaksanakan organ pemerintahan. Menurut Hans Kelsen, tugas negara meliputi politik sebagai etik, yaitu memilih tujuan kemasyarakatan, dan politik sebagai tehnik, yakni bagaimana merealisasikan tujuan tersebut. ${ }^{10}$

Jika konsistensi pemahaman nilai-nilai dan norma hukum dalam berpolitik juga menjadi bagian penting dalam mengupayakan terwujudnya tujuan negara hukum kesejahteraan, maka terdapat kiat tertentu dalam pemahaman nilai-nilai dan norma hukum berpolitik praktis yang meliputi kepatutan terhadap norma hukum yang berbentuk peraturan perundang-undangan dalam rangka berpolitik praktis; Melaksanakan ketentuan hukum dengan memperhatikan nilai-nilai keadilan, kemanfaatan dan kepastian hukum yang berfungsi sebagai roh berpolitik; Mengedepankan keutuhan bangsa atau nasionalisme; Konsisten untuk nguri-uri atau melestarikan sifat sosial, gotong royong, musyawarah, toleransi dan kepedulian (ciri guyub rukun) yang kesemuanya itu bagian dari living law; serta Memberi dan menerima kritisi yang konstruktif sesuai dengan tata peraturan perundang-undangan yang berlaku atas kinerja pemerintahan; Mempertahankan dan mengamalkan Pancasila sebagai pandangan hidup dan jati diri bangsa dalam menentukan dan melakukan berpolitik praktis; dan Mempertahankan dan berupaya

\footnotetext{
${ }^{8}$ Bachsan Mustafa, Pokok-Pokok Hukum Administrasi Negara, Citra Aditya Bakti, Bandung, 1990, h. 8.

${ }^{9}$ Riawan Tjandra, Hukum Administrasi Negara, Universitas Atmajaya, Yogyakarta, 2008, h. 6.

${ }^{10}$ Ridwan HR, Hukum Administrasi Negara, Raja Grafindo Persada, Jakarta, 2006, h. 13-14.
} 
mewujudkan cita bangsa meskipun banyak tantangan yang seiring dengan prinsip penegakan hukum dalam menyelesaikan permasalahan yang terjadi dalam berpolitik praktis.

Jika semua ini dilakukan sesuai dengan peraturan perundangan yang berlaku akan memberikan kemanfaatan terutama bagi masyarakat tentang arti penting pemahaman nilai-nilai dan norma hukum dalam berpolitik praktis diantaranya mampu membentuk perilaku politik yang cinta damai. Termasuk pula meningkatkan kesadaran hukum dan terselenggaranya proses penegakan hukum yang diperlukan dalam menyelesaikan setiap bentuk problematik hukum di dalam berpolitik praktis.

Adapun yang lebih penting lagi, bahwa pemahaman nilai-nilai dan norma hukum ini akan mendukung terwujudnya kesejahteraan rakyat, akan tetapi sebaliknya justru jika masih dilangsungkan perilaku arogansi berpolitik praktis niscaya akan terjadi konflik yang takkan mencederai demokrasi, HAM dan nilai dasar dalam kehidupan bermasyarakat, berbangsa dan bernegara.

Terkait dengan hal yang demikian itu berarti hukum merupakan penjelmaan dari jiwa serta cara berpikir masyarakat, artinya hukum merupakan penjelmaan dari struktur rohaniyah suatu masyarakat. Hukum merupakan penjilmaan dari nilai-nilai sosial budaya dari golongan yang membentuk hukum tersebut. ${ }^{11}$

Hukum merupakan norma yang mengajak masyarakat untuk mencapai cita-cita keadaan tertentu, tetapi tanpa mengabaikan dunia kenyataan dan oleh karenanya ia digolongkan kedalam norma kultur. Setiap masyarakat memiliki struktur dan substansi hukum sendiri. Yang menentukan apakah substansi dan struktur hukum tersebut diataati atau sebaliknya juga dilanggar adalah sikap dan perilaku sosial masyarakatnya, dan karena itu untuk memahami apakah hukum itu menjadi efektif atau tidak sangat tergantung pada kebiasaan ataucustom, kultur atau culture, tradisi-tradisi atau traditions dan norma-norma informal atau informal norms yang diciptakan dan dioperasionalkan dalam masyarakat yang bersangkutan.

Dengan demikian penegakan hukum dalam perspektif berpolitik praktis mengandung pandangan sebagai berikut:

\footnotetext{
${ }^{11}$ Soerjono Soekanto, Op.Cit., h. 33.
}

Pertama, Dari sisi hukum yang mengemban fungsi ekspresif, yakni mengungkapkan pandangan hidup, nilai-nilai budaya dan keadilan;

Kedua, Dari sisi hukum yang mengemban fungsi instrumental, yakni sarana untuk menciptakan dan memelihara ketertiban, stabilitas dan prediktabilitas, sarana untuk melestarikan nilai-nilai budaya dan mewujudkan keadilan, sarana pendidikan serta pengabdian masyarakat dan sarana pembaharuan masyarakat (mendorong, mengkanalisasi dan mengarahkan perubahan masyarakat). ${ }^{12}$

Berdasarkan pemahaman tersebut terlihat, bahwa hal yang perlu dipahami oleh seluruh komponen dalam proses pemahaman nilai-nilai dan norma hukum seiring dengan penegakan hukum dalam perspektif berpolitik praktis harus selalu mengacu pada hukum sebagai putusan otoritatif (positivitas); hukum sebagai suatu tatanan (koherensi); hukum sebagai pengaturan hubungan antar manusia yang tepat (keadilan); hukum sebagai penjabaran nilai-nilai fundamental dan luhur ke dalam berbagai perangkat aturan perilaku (martabat manusia). ${ }^{13}$

Dalam melaksanakan proses berpolitik praktis seiring penegakan hukum, maka perilaku politik dan kesadaran hukum adalah yang menjadi tolok ukur terselenggaranya fungsi dan peran penegakan hukum yang mampu menciptakan keseimbangan perwujudan tujuan hukum agar tercipta keadilan yang dicitakan masyarakat dan negara Indonesia. Untuk itu diperlukanlah pemahaman tentang nilai-nilai dan norma hukum yang tertulis sebagai hukum positif maupun dalam pengartian hukum sebagai living law sebagai penjabaran norma hukum.

Pemahaman norma hukum dalam pengartian yang tertulis sebagai hukum positif dapat dilihat dari berbagai bentuk hukum yang berlaku dalam keseharian dan yang berlaku saat ini atau ius constitutum. Berbagai ketentuan hukum yang harus dipatuhi dan ditaati oleh seluruh warga masyarakat. Sedangkan hukum sebagai living law dimaksudkan disini adalah beberapa aturan hukum yang tidak tertulis, akan tetapai masyarakat sangat mematuhi dan melaksanakan sebagai aturan kehidupan sehari-

${ }^{12}$ Arief Sidharta, Refleksi tentang Struktur Ilmu Hukum, Mandar Maju, Bandung, 1999, h. 189.

${ }^{13}$ Mochtar Kusumaatmadja, Fungsi dan Perkembangan Hukum dalam Pembangunan Nasional, Lembaga Penelitian Hukum dan Kriminologi FH-UNPAD, Bandung, 1996, h. 49. 
hari yang digunakan dalam menyelesaikan berbagai persoalan hukum yang terjadi di dalam masyarakat.

Ketidakmengertian dan pembiaran melakukan berpolitik yang tidak sesuai dengan nilai-nilai dan norma hukum akan menyulitkan pendidikan politik dan pelaksanaan proses penegakan hukum, sehingga hal itu akan mencederai nilai-nilai dasar yakni keadilan, kemanfaatan dan kepastian hukum.

Konsep dasar negara kesejahteraan sebagai salah satu tujuan pemahaman nilai-nilai dan norma hukum dalam berpolitik praktis dengan bertumpu mengedepankan peran hukum. Menurut Mahfud MD, di dalam paradigma pembangunan hukum, Pancasila sekurang-kurangnya memiliki empat kaidah penuntun yang jadi pedoman dan pembentukan dan penegakan hukum di Indonesia. Pedoman ini juga dapat digunakan sebagai dasar melakukan pemahaman nilai-nilai dan norma hukum dalam berpolitik praktis dengan memperhatikan watak hukum yang terbentuk, yaitu hukum harus melindungi segenap bangsa dan menjamin keutuhan bangsa dan karenanya tidak boleh ada hukum yang menanamkan benih disintegrasi, hukum harus menjamin keadilan sosial, dan hukum harus dibangun secara demokratis sekaligus membangun demokrasi sejalan dengan nomokrasi (negara hukum), serta hukum tidak boleh diskriminatif.

Dengan demikian tugas negara dalam negara kesejahteraan merupakan pengemban atau costudian amanat rakyat. Negara kesejahteraan adalah negara atau pemerintah tidak semata-mata sebagai penjaga keamanan atau ketertiban masyarakat saja, akan tetapi merupakan pemikul utama tanggung jawab untuk mewujudkan keadilan sosial, kesejahteraan umum dan sebesar-besar kemakmuran rakyat. Terciptanya proses pemahaman nilai-nilai dan norma hukum berpolitik praktis seiring proses penegakan hukum yang baik, maka akan tercipta negara kesejahteraan.

\section{PENUTUP}

\section{Kesimpulan}

Pemahaman nilai-nilai dan norma hukum dalam berpolitik praktis sangat diperlukan dalam melaksanakan dalam rangka berkehidupan bermasyarakat, berbangsa dan bernegara sebagai parameter das sollen dan das sein (harapan dan kenyataan) terwujudnya good gouvernance dan kesejahteraan rakyat khususnya di daerah sesuai dengan cita hukum dan cita bangsa berdasarkan Pancasila dan UUD NRI Tahun 1945 serta peraturan perundangan yang berlaku.

\section{Saran}

Perlu merekonstruksi tatanan hukum yang lebih partisipatif dan humanis dan politik hukum yang tidak merugikan rakyat, bangsa dan negara terutama dalam proses penegakan hukum terhadap pelaku politik yang mengingkari konstitusi dan cita bangsa.

\section{DAFTAR PUSTAKA}

\section{Peraturan Perundang-undangan:}

Undang-Undang Dasar Negara Republik Indonesia Tahun 1945.

Undang-Undang Nomor 2 Tahun 2011 tentang Partai Politik.

Undang Undang Nomor 15 Tahun 2011 tentang Penyelenggaraan Pemilu.

Undang-Undang Nomor 23 Tahun 2014 tentang Pemerintahan Daerah.

\section{Buku:}

Sidharta, Bernard Arief. 1999. Refleksi tentang Struktur Ilmu Hukum. Bandung: Mandar Maju.

Mustafa, Bachsan. 1990. Pokok-Pokok Hukum Administrasi Negara. Bandung: Citra Aditya Bakti.

Koentjoro, Diana Halim. 2004. Hukum Administrasi Negara. Bogor: Ghalia Indonesia.

Utama, I Made Arya. 2007. Hukum Lingkungan, Sistem Hukum Perizinan, Berwawasan Lingkungan untuk Pembangunan Berkelanjutan. Bandung: Pustaka Sutra.

Kusumaatmadja, Mochtar. 1996. Fungsi dan Perkembangan Hukum dalam Pembangunan Nasional. Bandung: Lembaga Penelitian Hukum dan Kriminologi FH-UNPAD.

Tjandra, Riawan. 2008. Hukum Administrasi Negara. Yogyakarta: Universitas Atmajaya.

Ridwan H.R. 2006. Hukum Administrasi Negara. Jakarta: Raja Grafindo Persada.

Soekanto, Soerjono dan Mustafa Abdullah. 1982. Sosiologi Hukum dalam Masyarakat. Jakarta: Rajawali.

Rahardjo, Satjipto. 1986. Ilmu Hukum. Bandung: Alumni. 


\section{Jurnal:}

Kusuma, RMAB. 2006. Negara Kesejahteraan dan Jaminan Sosial. Jurnal Konstitusi. Vol. 3. Februari 2006. Jakarta: Mahkamah Konstitusi RI.
Manan, Bagir dan Kuntana Magnar. "Mewujudkan kedaulatan Rakyat Melalui Pemilihan Umum" dalam Bagir Manan (editor) Kedaulatan Rakyat. 